\title{
Response of Farmyard Manure and Inorganic Fertilizers for Sustainable Yield of Carrot (Daucus carota $\mathbf{L}$.) in Northern Nigeria
}

\author{
* ${ }^{1}$ Ahmed, A.; ${ }^{2}$ Sambo, B. E.; ${ }^{1}$ Odion, E. C. and ${ }^{1}$ Arunah, U. L. \\ ${ }^{I}$ Department of Agronomy, Institute for Agricultural Research, Ahmadu Bello University, P.M.B.1044, Samaru, \\ Zaria-Nigeria. \\ ${ }^{2}$ Department of Crop Science, Federal University Dutse, P.M.B.7156, Jigawa State - Nigeria.
}

\begin{abstract}
In Nigeria, Carrot (Daucus carota) has become common in the Northern part of the Country, where it is grown for the enlarged tap roots. It has a high nutritive value. The enlarged tap root contains large quantities of carotene which is an excellent source of vitamin A. Carrot responds favorably to both organic and inorganic fertilizers. However, most soils of the Nigerian savannah are ferrugineous tropical soils which are generally low in fertility, with very low organic matter and nitrogen contents. In addition, the long severe dry season experienced in a savanna region, further aggravated by annual bush burning, inevitably results in the depletion of the organic matter (OM) content of the soil, thus aggravating their already inherently low OM levels. As a result, these soils are incapable of sustaining crop productivity for even one growing season. Consequently, low average crop yields have been recorded. It is more than likely that a sound fertilizer regime may be needed to increase crop yields. Consequently, this study was carried out at two locations (Samaru and Kadawa) during the 1991/92 dry seasons to determine the effect of nitrogen, phosphorous and organic farm yard manure (FYM) on the yield of carrot (Daucus carota). The treatments were laid out in factorial combinations and laid out in a randomized complete block design and replicated three times. Slightly sunken beds of $1.5 \times 2.0 \mathrm{~m}$ constituted the plots. Results showed that nitrogen $(\mathrm{N})$ and phosphorous $\left(\mathrm{P}_{2} \mathrm{O}_{5}\right)$ application significantly affected root length, root diameter and marketable yield at Samaru and Kadawa. Similarly, farmyard manure (FYM) significantly increased root length, root fresh weight, and marketable yield at both locations. Consequently, it is concluded that, the application of phosphorous significantly increased the marketable yield. Also, FYM application at 20t ha $a^{-1}$ significantly increased most yield characters and marketable yield at harvest. However, it is recommended that further comprehensive and comparative studies on organic fertilization verses conventional (synthetic, chemical input) production systems are still needed before any meaningful conclusions and recommendations can be made for the degraded soils of the savannah regions of Nigeria.
\end{abstract}

Key words: Organic matter, nutrient, food and nutrition, security, sustainable, productivity

\section{Introduction}

In Nigeria, carrot is relatively a recent addition to the diet prior to the mid 50s. It was mainly grown by the expatriates who also purchased the 'commercial' crops. Currently the crop is become commonly grown in the Northern part of the Country, particularly at the end of the dry season - March to May [1].

Global production of carrot is estimated at 23,321 metric tonnes; and China is reportedly the leading producer of carrot with an estimated output of 8,395,500 metric tonnes; while Europe contributes an estimated total of 7,484 metric tonnes. Africa's global share of production is estimated at 1,054 metric tonnes [2]; while in Nigeria, estimated production is reported to have stood at 23,500 metric tonnes fom 27,500 hectares of land [3]. Reported carrot yields are generally low in Nigeria, even under good crop management, compared to the yields from Europe and elsewhere. For instance [4] reported obtaining yields of up to $14-23 \mathrm{t} \mathrm{ha}^{-1}$ of carrot in Sokoto, Nigeria. While in Europe, average yields ranging from $30-60 \mathrm{tha}^{-1}$ have been reported [2].

Among succulent vegetables, carrot ranks third in world production. This is because the crop which is easy to grow has a long period of harvest; transports well and stores for relatively long period of time at low temperatures [5]. Carrot is also in-expensive and popular, particularly in Northern Nigeria where it has great production potentials during the dry season when temperatures are favorably low and the crop is least affected by pest and diseases. In addition there is relatively cheap labor during the period and it attracts a fair produce price and consequently is a good source of income to the resource poor farmers.

Carrot responds favorably to both organic and inorganic fertilizer, but the rate depends on the nutrient status of the soil. For instance, carrot was reported to respond favorably to nitrogen fertilization. At Samaru, [6] reported that the yield of marketable carrot roots was related to fertilizer application; with significant yield increase in response to increasing rate of sulphate of ammonia from 0 to $75 \mathrm{~kg} \mathrm{ha}^{-1}$. 
In the savanna area of Nigeria, FYM is valued mainly because of its phosphorous content as most savanna soils are deficient in phosphorous [7, 8]. Thus, the remarkable crop returns from FYM may be attributed largely to its $\mathrm{P}$ and micronutrient contents [9], and to a lesser extent $\mathrm{N}$ and $\mathrm{K}$.

In essence, carrot (Daucus carota L.) has been reported to respond favorably well to mineral fertilizers and organic manure. [10] reported that farmyard manure (FYM) and compost were the most popular forms of fertilizers for growing vegetables in Ghana. Similarly, In the U.K. high organic matter content, in the form of well rotted farmyard manure, applied a few months before planting, to avoid getting forked roots, is recommended [11]. In some other trial, organic fertilizers were applied with and without farmyard manure (FYM) on fodder carrot, and it was observed that, nitrogen, phosphorous and potassium tended to decrease the carotene content of the roots; but with all rates of $\mathrm{N}, \mathrm{P}$ and $\mathrm{K}$, the carotene content was higher when FYM was added than without [12].

In this regard, in Nigeria, research work on carrot crop is very scanty and much in the primary stages (6Green, 1973). However, considering the advantages of carrot production compared with other vegetables, and its increasing appeal for human consumption, it has become apparent that research interest be rekindled in its production. In addition, it has been reported that most soils of the Nigerian savannah are ferruginous tropical soils which are generally low in fertility, with very low organic matter and nitrogen status [13]; in spite of the fact that in the Nigerian savannah, it has been estimated that about 31.41 million metric tonnes of crop residues was produced during the $1970-71$ season, but this require careful management before it can optimally be utilized and/or become beneficial as a source of organic matter [14]. On the other hand, total phosphorous content of savannah soils are often considered high, with average values of 147.0 and $977 \mathrm{ppm}$ respectively, in the surface and subsurface soils respectively [15].

But, it has been highlighted that the long severe dry season experienced in a savanna regions, further aggravated by annual bush burning, inevitably results in the depletion of the organic matter (OM) content of the soil, thus further worsening their already inherently low organic matter levels. As a result, these soils are incapable of sustaining good crop productivity for even one growing season [16]. All these factors reduces the phosphorous contents of the savanna soils through organic matter (OM) source depletion [14]; and of course its availability. Generally low average crop yields have been associated with these factors.

Researchers have been reported to focus on carrot yield responses to $\mathrm{N}$ fertilization but seldom evaluated carrot quality characteristics, such as sugar or carotenoid concentrations [17, 18]. Nitrogen application has been reported to, in some instances, affect vegetable quality [19]. Greater fertilization rates of N, P, and K led to reduced sugar concentration of carrots experiments in Finland [20]. However, [21] found that yield increased with $\mathrm{N}$ fertilization depending on planting date; $150 \mathrm{~kg} \mathrm{ha}^{-1} \mathrm{~N}$ maximized yield for November and December plantings but $180 \mathrm{~kg} \mathrm{ha}^{-1} \mathrm{~N}$ was sufficient for January planting. Generally, they highlighted that those $\mathrm{N}$ fertilization rates that maximized carrot yield also maximized carrot quality as determined by sugar and carotenoid concentrations.

In spite of all this, $[22,23]$ observed that organic manures have the limitations of being very low in nutrient content per unit weight compared to inorganic fertilizers; and slow in nutrient release. Therefore, a more ideal mineral supply situation may necessitate the adoption of an integrated approach to the use of these nutrient sources.

It is more than likely that a sound fertilizer programme may be needed to increase crop yields. Consequently, this study was carried out with the objective of determining the effect of nitrogen, phosphorous and farmyard manure (FYM) on the yield and quality of carrot (Daucus carota L.).

\section{Materials and Methods}

Two trials were conducted during the 1991 dry season on the farms of the Institute for Agricultural Research, Ahmadu Bello University, Samaru (Latitude $11^{\mathrm{O}} 11^{\mathrm{I}} \mathrm{N}$ and $7^{\mathrm{O}} 38^{\mathrm{I}} \mathrm{E}$ ) in Northern Guinea Savanna Ecological Zone of Nigerian and the Irrigation Research Station of the Institute for Agricultural Research, Ahmadu Bello University Kadawa $\left(11^{\mathrm{O}} 39^{\mathrm{I}} \mathrm{N}\right.$ and $\left.08^{\mathrm{O}} 02^{\mathrm{I}} \mathrm{E}\right)$ in the Sudan Savanna ecological zone of Nigeria. Samaru in the northern Guinea Savannah is located around the middle of Nigeria is a belt of mixtures of less trees and shorter grasses in the north; occasioned by local climatic conditions of low rainfall and long dry periods - with a distinct dry (between November and March) and wet seasons (between April and October). Usually, rainfall in the region establishes between mid-May and early June and peaks in July/August. Total annual rainfall ranges between $883-1062 \mathrm{~mm}$, with an average of $945.20 \mathrm{~mm}$. The dry season starts at about midOctober and extends to the end of April. The mean minimum and maximum temperatures during the rainy seasons range between $14-22^{\circ} \mathrm{C}$ and $29-34^{\circ} \mathrm{C}$ respectively. While Kadawa, in the Sudan Savannah, is found in the North West - northern states - bordering the Niger republic. It is characterized by low amounts of rainfall (usually less than $1000 \mathrm{~mm}$ ) and prolonged dry season (6-9 months); and sustained fewer shorter, stunted trees, hardly above $15 \mathrm{~m}$ and shorter grasses $(1.5-2 \mathrm{~m})$ than the Guinea Savannah. In both ecologies, the vegetation has 
undergone destruction in the process of bush clearing, burning and degradation for agriculture and other human activities; in addition to devastation due to animal husbandary [24].

Soils on the experimental sites at Samaru and Kadawa were Loam and Clay Loam respectively. These soils are described as well drained, often leached ferruginous tropical soils [25]. They are characterized by low $\mathrm{pH}$, cation exchange capacity, low organic carbon and nitrogen but with high level of potassium. The proceeding crops at the first and second experimental sites were tomatoes and onions respectively.

The treatment were made up of four levels of nitrogen $\left(0,50,100,150 \mathrm{~kg} \mathrm{ha}^{-1}\right)$, three levels of phosphorous $(0$, 50 and $\left.100 \mathrm{~kg} \mathrm{P}_{2} \mathrm{O}_{5} \mathrm{ha}^{-1}\right)$ and two levels of FYM $\left(0\right.$, and $\left.20 \mathrm{tha}^{-1}\right)$ in factorial combinations and laid out in a randomized complete block design and replicated three times. The sources of nitrogen, phosphorous and FYM were calcium ammonium nitrate, single superphosphate and well rotted cow dung respectively.

The experimental site was ploughed once, harrowed twice, raked free of stones and plot and then manually prepared into series of slightly sunken beds each of $1.5 \times 2.0 \mathrm{~m}$ dimension which constituted the plots. The FYM was applied in one single dose, a week before sowing by broadcasting and thorough mixing with the top soil. The $\mathrm{P}$ - fertilizer was also applied to the appropriate plots in a single application at seed bed preparation time. The $\mathrm{N}$ - fertilizer was applied in 2 equal split doses at 2 and 4 weeks after sowing (WAS) in bands about $3 \mathrm{~cm}$ deep and away from the line of drilled seedlings. The seed drills were $30 \mathrm{~cm}$ apart. At 3 to 4 weeks after emergence, the seedlings were thinned to an intra - row spacing of $5 \mathrm{~cm}$ apart. During early seedlings growth, weeds were hand - pulled to prevent seedlings damage, while hoe - weeding was later employed as often as necessary.

Irrigation water was the source of water at both experimental sites. Surface flood irrigation of the beds was provided every $3-4$ days throughout the period of the experiments at Samaru and once a week at Kadawa. The matured carrot roots were harvested at $10 \mathrm{WAS}$, when the crown diameter was about $3-3.5 \mathrm{~cm}$. The beds were pre - irrigated before harvesting so as to facilitate lifting out of roots.

Observations on the yield parameter were conducted at weekly intervals beginning from 5 weeks after sowing (WAS). Dry weight of root, root length, root diameter, total fresh weight of roots, and root fresh weight per plant were determined. The total dry weight per plant was determined by oven drying to a constant weight at a temperature of $70^{\circ} \mathrm{C}$ and then weighed. Roots were harvested when crown diameter was between 2.5 to $3.5 \mathrm{~cm}$ i.e. at about $9-12$ weeks after sowing (WAS).

The crop data collected were statistically analyzed to determined treatment effects for significance using ' $\mathrm{F}$ ' test [26]. Treatment means were compared using Duncan Multiple Range test (DMRT) at 5\% level of significance [27].

\section{Results}

\subsection{Effect of Application of Inorganic and Farmyard Manure (FYM) on the Yield of Carrot (Daucus}

\section{Carota L.)}

\subsubsection{Root length $(\mathbf{c m})$}

Nitrogen application significantly affected root length at Samaru at 5WAS only and at Kadawa, 7 and 9 WAS (Table 1). Increasing level of $\mathrm{N}$ up to $100 \mathrm{~kg} \mathrm{~N}^{-1}$ has no significant effect on root length except at Kadawa during the 9 WAS. Further increase in $\mathrm{N}$ up to $150 \mathrm{~kg} \mathrm{ha}^{-1}$ however led to significant growth in root length.

Only at Kadawa did the application of $\mathrm{P}_{2} \mathrm{O}_{5}$ significantly influenced root length at 7 WAS. The application of $100 \mathrm{~kg} \mathrm{P}_{2} \mathrm{O}_{5} \mathrm{ha}^{-1}$ increased root length compared with no phosphorous treatment but was similar to the $50 \mathrm{~kg}_{2} \mathrm{O}_{5}$ treatment.

FYM significantly increased root length at both locations during the period of study.

\section{1. 2. Root diameter $(\mathrm{cm})$}

The diameter of carrot roots was unaffected by both $\mathrm{N}$ and $\mathrm{P}_{2} \mathrm{O}_{5}$ application (Table 2). The application of FYM had no significant effect on root diameter at both locations during the period of study.

\section{1. 3. Root fresh weight per plant (gm)}

Root fresh weight per plant was significantly affected by nitrogen levels at both locations at 9 WAS (Table 3). At 9 WAS, root fresh weight increased significantly with each increase in $\mathrm{N}$ level.

FYM application significantly increased root fresh weight per plant at Kadawa throughout the sampling periods and at Samaru at 5 and 9 WAS.

The application of $\mathrm{P}_{2} \mathrm{O}_{5}$ had no significant effect on root fresh weight.

\section{1. 4. Yield (Marketable) $\mathrm{kg} \mathrm{ha}^{-1}$ )}

The effects of nitrogen, phosphorous and FYM on (marketable) root yield ha-1 at final harvest were significant at both locations (Table 4). The marketable yield of carrot increased significantly with each added 
level of $\mathrm{N}$ and $\mathrm{P}_{2} \mathrm{O}_{5}$. Application of FYM also increased significantly the marketable yield ha ${ }^{-1}$ of carrot at both locations.

\section{1. 5. Total soluble sugar $(\%)$}

The effect of the treatment in total soluble sugar content of carrot root at Samaru is presented on (Table 5). Only nitrogen application significantly affected the total soluble sugar content. Each successive increase in the level of $\mathrm{N}$ up to the highest of $150 \mathrm{kgN} / \mathrm{ha}$ resulted in the significant increase in the percent of soluble sugar content of carrot roots. Highest rate of increase in percent soluble occurred when the level of $\mathrm{N}$ was raised from 50 to $100 \mathrm{~kg} / \mathrm{ha}$.

The application of phosphorous and FYM had no significant effect on the total soluble sugar content of carrot.

Table 1: Root Length (cm) of Carrot as Influenced by the Application of N, P and FYM at Samaru and Kadawa 1991.

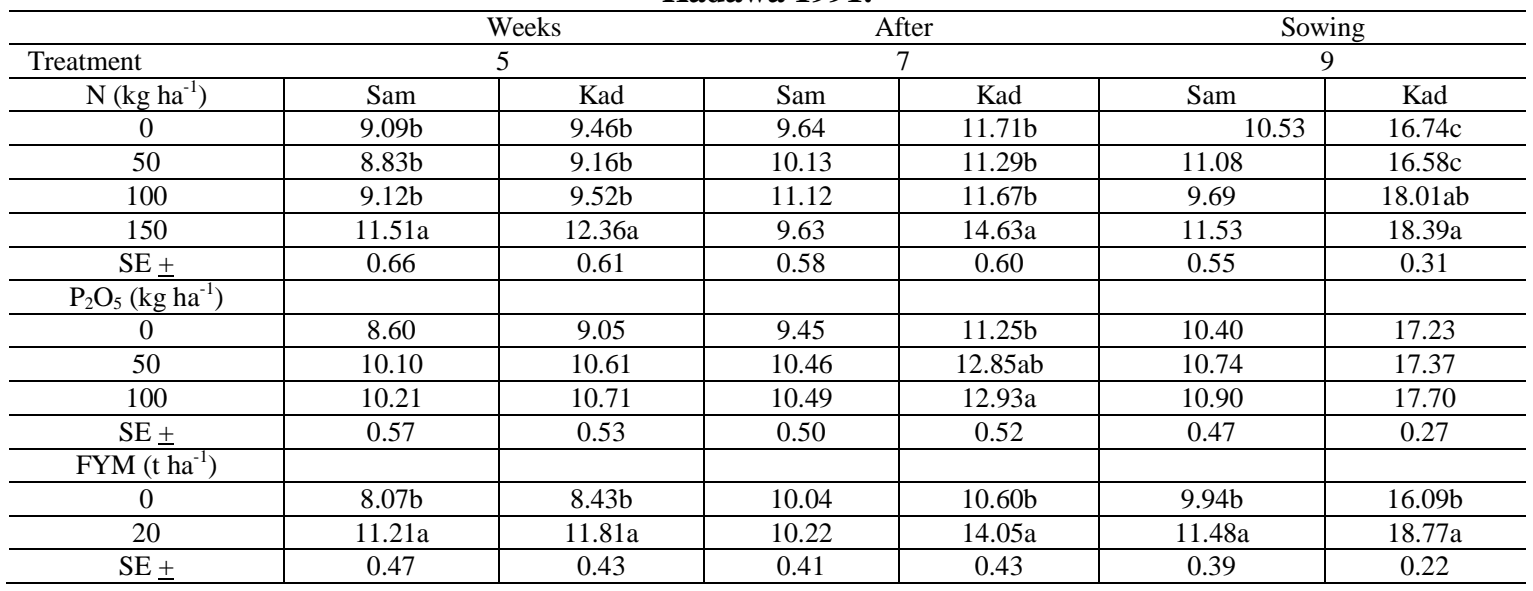

Means of treatment set followed by unlike letter(s) are significantly difference at level of significance using DMRT.

Sam $=$ Samaru $; \mathbf{K a d}=$ Kadawa

Table 2: Root Diameter (cm) of Carrot as Influenced by the Application of N, P, and FYM at Samaru and Kadawa, 1991.

\begin{tabular}{|c|c|c|c|c|c|c|}
\hline & \multicolumn{2}{|c|}{ Weeks } & \multicolumn{2}{|c|}{ After } & \multicolumn{2}{|c|}{ Sowing } \\
\hline Treatment & \multicolumn{2}{|c|}{5} & \multicolumn{2}{|c|}{7} & \multicolumn{2}{|c|}{9} \\
\hline 0 & 9.94 & 1.18 & 2.10 & 2.23 & 2.34 & 2.66 \\
\hline 100 & 1.06 & 1.25 & 2.32 & 2.32 & 2.82 & 2.73 \\
\hline 150 & 1.82 & 1.75 & 2.14 & 2.84 & 2.74 & 2.77 \\
\hline $\mathrm{SE} \pm$ & 0.26 & 0.20 & 0.18 & 0.20 & 0.16 & 0.06 \\
\hline 0 & 1.18 & 1.38 & 2.06 & 2.49 & 2.38 & 2.67 \\
\hline 50 & 1.48 & 1.66 & 2.30 & 2.78 & 2.50 & 2.78 \\
\hline 100 & 1.32 & 1.30 & 2.22 & 2.37 & 2.70 & 2.78 \\
\hline $\mathrm{SE} \pm$ & 0.22 & 0.17 & 0.16 & 0.18 & 0.14 & 0.06 \\
\hline \multicolumn{7}{|l|}{ FYM $\left(\mathrm{t} \mathrm{ha}^{-1}\right)$} \\
\hline $\mathbf{0}$ & 1.24 & 1.47 & 2.26 & 2.57 & 2.44 & 2.54 \\
\hline
\end{tabular}

Means of treatment set followed by unlike letter(s) are significantly difference at level of significance using DMRT.

Sam $=$ Samaru $;$ Kad $=$ Kadawa 
Table 3: Root Fresh Weight per Plant (gm) of Carrot as Influenced by the Application of N, P, and FYM at Samaru and Kadawa, 1991.

\begin{tabular}{|c|c|c|c|c|c|c|}
\hline & \multicolumn{2}{|c|}{ Weeks } & \multicolumn{2}{|c|}{ After } & \multicolumn{2}{|c|}{ Sowing } \\
\hline Treatment & \multicolumn{2}{|c|}{5} & \multicolumn{2}{|c|}{7} & \multicolumn{2}{|c|}{9} \\
\hline $\mathrm{N}\left(\mathrm{kg} \mathrm{ha}^{-1}\right)$ & Sam & Kad & Sam & Kad & Sam & Kad \\
\hline 0 & 5.85 & 6.29 & 20.30 & 22.25 & $24.62 d$ & $28.02 \mathrm{~d}$ \\
\hline 50 & 6.39 & 6.82 & 18.90 & 22.82 & $29.39 \mathrm{c}$ & $30.91 \mathrm{c}$ \\
\hline 100 & 5.20 & 5.68 & 20.00 & 21.69 & $32.41 \mathrm{~b}$ & $33.76 \mathrm{~b}$ \\
\hline 150 & 6.24 & 6.76 & 21.80 & 22.76 & $39.15 a$ & $36.68 \mathrm{a}$ \\
\hline $\mathrm{SE} \pm$ & 0.86 & 0.89 & 2.58 & 0.88 & 0.92 & 1.57 \\
\hline \multicolumn{7}{|l|}{$\left.\mathrm{P}_{2} \mathrm{O}_{5} \mathrm{~kg} \mathrm{ha}^{-1}\right)$} \\
\hline $\mathbf{0}$ & 4.61 & 5.04 & 17.70 & 21.06 & 30.45 & 31.80 \\
\hline 50 & 5.97 & 6.46 & 22.20 & 22.44 & 31.52 & 32.35 \\
\hline 100 & 7.18 & 7.66 & 20.80 & 23.66 & 32.22 & 32.87 \\
\hline $\mathrm{SE} \pm$ & 0.74 & 0.76 & 2.23 & 0.76 & 0.80 & 1.36 \\
\hline \multicolumn{7}{|l|}{ FYM $\left(\mathrm{t} \mathrm{ha}^{-1}\right)$} \\
\hline 0 & $4.17 b$ & $4.55 \mathrm{~b}$ & 20.10 & $20.52 b$ & $22.55 b$ & $27.77 b$ \\
\hline 20 & $7.67 \mathrm{a}$ & $8.22 \mathrm{a}$ & 20.40 & $24.24 \mathrm{a}$ & $24.24 \mathrm{a}$ & 36.92 \\
\hline $\mathrm{SE} \pm$ & 0.61 & 0.62 & 1.82 & 0.62 & 0.65 & 1.11 \\
\hline
\end{tabular}

Means of treatment set followed by unlike letter(s) are significantly difference at level of significance using DMRT.

Sam $=$ Samaru; $\mathbf{K a d}=$ Kadawa

Table 4: Effect of N, P and FYM on the Marketable Yield of Carrot at Samaru and Kadawa, 1991

\begin{tabular}{|c|c|c|}
\hline Treatments & \multicolumn{2}{|c|}{ Yield t ha ${ }^{-1}$ (tons) } \\
\hline $\mathbf{N}\left(\mathrm{kg} \mathrm{ha}^{-1}\right)$ & Samaru & Kadawa \\
\hline 0 & $6.10 \mathrm{~d}$ & $12.82 \mathrm{~d}$ \\
\hline 50 & $12.26 \mathrm{c}$ & $15.82 \mathrm{c}$ \\
\hline 100 & $15.44 \mathrm{~b}$ & $20.31 b$ \\
\hline 150 & $20.01 \mathrm{a}$ & $21.50 \mathrm{a}$ \\
\hline $\mathrm{SE} \pm$ & 0.29 & 0.17 \\
\hline \multicolumn{3}{|l|}{$\mathrm{P}_{2} \mathrm{O}_{5}\left(\mathrm{~kg} \mathrm{ha}^{-1}\right)$} \\
\hline 0 & $10.54 \mathrm{c}$ & $15.57 \mathrm{c}$ \\
\hline 50 & $13.38 \mathrm{~b}$ & $18.14 b$ \\
\hline 100 & $16.16 \mathrm{a}$ & $20.65 a$ \\
\hline $\mathrm{SE} \pm$ & 0.25 & 0.15 \\
\hline \multicolumn{3}{|l|}{ FYM $\left(\mathrm{t} \mathrm{ha}^{-1}\right)$} \\
\hline 0 & $10.49 \mathrm{~b}$ & $15.06 \mathrm{~b}$ \\
\hline 20 & $16.89 \mathrm{a}$ & $20.42 \mathrm{a}$ \\
\hline $\mathrm{SE} \pm$ & 0.20 & 0.12 \\
\hline
\end{tabular}

Means of treatment set followed by unlike letter(s) are significantly difference at level of significance using DMRT.

Table 5: Total Soluble Sugars (\%) as Influenced by N, P, and FYM application at Samaru , 1991

\begin{tabular}{c|c}
\hline Treatments & Total soluble sugars (\%) \\
\hline $\mathbf{N}\left(\mathbf{k g ~ h a}^{-1}\right)$ & Samaru \\
\hline $\mathbf{0}$ & $6.10 \mathrm{~d}$ \\
\hline $\mathbf{5 0}$ & $12.26 \mathrm{c}$ \\
\hline $\mathbf{1 0 0}$ & $15.44 \mathrm{~b}$ \\
\hline $\mathbf{1 5 0}$ & $20.01 \mathrm{a}$ \\
\hline $\mathbf{S E} \pm$ & 0.29 \\
\hline $\left.\mathbf{P}_{\mathbf{2}} \mathbf{O}_{\mathbf{5}} \mathbf{( k g ~ h a}^{-1}\right)$ & $10.54 \mathrm{c}$ \\
\hline $\mathbf{0}$ & $13.38 \mathrm{~b}$ \\
\hline $\mathbf{5 0}$ & $16.16 \mathrm{a}$ \\
\hline $\mathbf{1 0 0}$ & 0.25 \\
\hline $\mathbf{S E} \pm$ & \\
\hline $\mathbf{F Y M}\left(\mathbf{t} \mathbf{h a}^{-1}\right)$ & $10.49 \mathrm{~b}$ \\
\hline $\mathbf{0}$ & $16.89 \mathrm{a}$ \\
\hline $\mathbf{2 0}$ & 0.20 \\
\hline $\mathbf{S E} \pm$ & \\
\hline
\end{tabular}

Means of treatment set followed by unlike letter(s) are significantly difference at level of significance using DMRT. 


\section{Discussion}

\subsection{Effect of Inorganic Fertilizers on the Yield of Carrot (Daucus Carota L.)}

The application of nitrogen significantly increased yield parameter measured, except root diameter, at Kadawa (Tables 1 - 4). However, it significantly increased root length and root fresh weight at Samaru. The observed differences in the two locations were probably due to the slight higher organic matter (OM) content of the soil at Kadawa compared to Samaru. Although root diameter increased with age, such increase was not significantly influenced by $\mathrm{N}$ levels. On the other hand, root length responded well to $\mathrm{N}$ application. It is likely that the growth in girth (diameter) is less responsive to $\mathrm{N}$ than the growth in length. The application of Nitrogen significantly increased the marketable root yield $\mathrm{ha}^{-1}$ at both locations. The yield increase was significant with each increasing level of nitrogen applied. Corroboratively, [6, 12, 28, 29, 30], have all reported significant increase in carrot root yields with $\mathrm{N}$ application.

The application of phosphorous had significant effect on root length only at Kadawa. This was probably because crop establishment and vigor were better at Kadawa than at Samaru. Slight water - logging of the crop at the early stage of growth in Samaru may have adversely affected the crop's response to P application especially as it was applied basally. The application of phosphorous had no significant effect on root diameter and root fresh weigh at both locations, and only the application of $100 \mathrm{~kg}_{2} \mathrm{O}_{5} \mathrm{ha}^{-1}$ produced significant difference on root length at Kadawa.

The reason for the lack of response of root diameter to $\mathrm{P}_{2} \mathrm{O}_{5}$ application is not very clear. Probably, this root character is more under genetic control and less sensitive to fertilizer rates. The yield of carrot root was significantly increased with each added level of phosphorous fertilizer at both locations. According to [31] and [32], phosphorous is important for plant growth since it is essential for good root establishment necessary for efficient mineral absorption and consequently improved growth and yield. [28] reported that $180 \mathrm{~kg} \mathrm{of}_{2} \mathrm{O}_{5} \mathrm{ha}^{-1}$ gave the higher yield effect after nitrogen; while [12] observed some yield increase when $90 \mathrm{~kg} \mathrm{P}_{2} \mathrm{O}_{5}$ ha $^{-1}$ was used. [6] also reported that, the application of $45 \mathrm{~kg} \mathrm{P}_{2} \mathrm{O}_{5}$ ha $^{-1}$ using single superphosphate resulted in a significant increase in both marketable and total yields of carrot.

\subsection{Effect of Farm Yard Manure (FYM) on Yield and Soluble Sugar Content of Carrot (Daucus Carota}

L.)

The application of FYM significantly increased all the yield characters measured at both locations except root diameter at Samaru (Tables 1 - 4). The ability of FYM to significantly influence this character at both locations may probably be due to the fact that it supplies nitrogen and phosphorous as reported by [33]; and also on its ability to improve the physio - chemical properties of the soils [34]; resulting in improved soil conditions and better nutrient availability.

The yield of carrot root responded significantly to FYM. Apart from the ability of FYM to supply nutrients, and improve the physico - chemical condition of the soil, it as well helped in the gradual release of its nutrients into the soil, which makes it an ideal input for good carrot crop yield. More so, FYM has high organic carbon (OC) content (13.51 and 14.21\%) for Samaru and Kadawa respectively and other macro and micro nutrients such as $\mathrm{Ca}, \mathrm{Mg}$ and $\mathrm{Fe}$ which are essential for good crop growth. These findings are in agreement with those of [35] and [12], who observed significant, increase in growth of both tops and roots of carrot with organic FYM application.

Total soluble sugar content of carrot root responded well to $\mathrm{N}$ fertilization. Improved vegetative growth and photosynthetic activity in response to $\mathrm{N}$ application might have been responsible for the increased sugar production (Table 5). This observation is consistent with that of [36], who observed increased content of total sugars from nitrogen application; and [21] who noted that generally, those $\mathrm{N}$ fertilization rates that maximized carrot yield also maximized carrot quality as determined by sugar and carotenoid concentrations. However, [37] observed a decrease in the content of monosaccharide at very high rates of nitrogen $(400 \mathrm{kgN} / \mathrm{ha})$. On the other hand, the application of phosphorous and FYM did not significant affect total soluble sugars. This is also consistent with the observation of [38] who also did not detect any appreciable effect on the accumulation of vitamin $\mathrm{C}$, carotene, thiamine and riboflavin as a result of phosphorous application. This only lends credence to the ongoing contentious debates as to whether foods produced from organic systems are better in quality than those produced from conventional (synthetic) systems. However, there can be no denying the fact that they are better considering the human, animal, ecological and environmental health implications [39].

\subsection{Organic Versus Inorganic Production Systems and Sustainability}

From the results of this experiment, it is clear that plots employing farmyard manure (FYM) recorded statistically similar yields comparable to conventional systems employing inorganic (synthetic) fertilizers inputs (Table 1 - 4). In fact, it is evident that the yield levels attained on plots with high $\left(20 \mathrm{t} \mathrm{ha}^{-1}\right)$ organic farmyard manure (FYM) inputs, required commensurately very high inputs $\left(50-150 \mathrm{~kg} \mathrm{ha}^{-1}\right)$ of inorganic chemical 
(synthetic) fertilizers to produce or attain statistically similar yield levels. This is explicitly indicative of the fact that agricultural yield in organic systems do not fall [39].

However, the use of synthetic inputs (chemical fertilizers) beyond their effects on crop yields, in recent times, has its drawback. It has been associated with serious damage to the environment. And of more serious human and animal health concern is the diminished food quality mainly due to chemical deposits (residues) on fruits, seeds, roots or tuber crops [40].

On the whole the rather slow build up could be explained in part to the fact that, after switching from synthetic inputs to organic systems, the farmers could/usually experience an initial decline in yields. But, after the agro-ecosystem is restored and organic management systems are fully implemented, yields increase significantly; because if agricultural systems are low in natural, social and human assets - either intrinsically low, or have become damaged by degradation - then a sudden switch to organic practices that rely on these assets will not be immediately successful and may take time to reach full potential [41, 42]. In this regard the benefits of organic productions systems are obvious. Organic agriculture relies on five capital assets for success (natural, social, physical and financial capital). It contributes to and builds up stock of these natural, social and economic resources over time [43,44]; thus improving food and nutrition security in a long-term, and in a sustainable manner $[39,45]$.

\subsection{Conclusion}

\section{Conclusions and Recommendations}

Nitrogen application at high rates $\left(150 \mathrm{~kg} \mathrm{ha}^{-1}\right)$ significantly increased the root length and marketable yield $\mathrm{ha}^{-1}$ of carrot. Similarly, the application of phosphorous slightly increased root length of carrot; but, significantly increased marketable yield $\mathrm{ha}^{-1}$ at high rates $\left(150 \mathrm{~kg} \mathrm{ha}^{-1}\right)$. Farmyard manure (FYM) application at $20 \mathrm{tha}^{-1}$ significantly increased most yield characters except the root diameter. Marketable yield $\mathrm{ha}^{-1}$ was also significantly increased by FYM. The fact must be underscored to both producers and consumers of this produce alike, of the negative and disastrous impact of the over "dumping" and/ or chemicalization of our soils, water, and environment; with the entire attendant health drawback. Hence, the positive impact and/ or advantages of organic production systems cannot be over emphasized.

\subsection{Recommendation (s)}

Even though FYM played a significant and complimentary role in the productivity of carrot (Daucus Carota L.), further comprehensive and comparative studies on organic systems verses conventional (synthetic chemical input) production systems are still needed before any meaningful conclusions and recommendations can be made for the savannah regions of Nigeria.

\section{References}

[1] H. D. Tindall, Commercial vegetable growing (Oxford university Press, London, 1983).

[2] World Carrot Museum, Carrot Production Statistics, 2013, http://www.carrotmuseum.co.uk/statistics.htm (accessed on 6 ${ }^{\text {th }}$ December, 2013)

[3] FAO, Production Year Book. Food and Agriculture Organization (FAO) of the United Nations. Rome, Italy, 2003, 67 - 103, in S. Sarkindiya, and A. I. Yakubu, Effect of Intra-row Spacing, Fertilizer Level and Period of Weeding on the Performance of Carrot (Daucus carota L.) in Sokoto Rima Valley, Sav. J. of Agric., 1 (1), 2006, 1-5

[4] S. Sarkindiya, and A. I. Yakubu, Effect of Intra-row Spacing, Fertilizer Level and Period of Weeding on the Performance of Carrot (Daucus carota L.) in Sokoto Rima Valley, Sav. J. of Agric. 1 (1), 2006, 1-5

[5] Yamaguchi M, World vegetables, principles, production and nutritional values (Ellis Horward Ltd., Chichester, England, 1983, 240 $-246$

[6] J. M. Green, Cultivars, fertilizers, crop protection and economics of carrot production in Northern Nigeria, Institute for Agricultural Research (I. A. R.) Samaru, Zaria, Nigeria, 1973.

V. Balasubranian, L. A. Nnadi, L. G. Lombin, and J. Y. Yayock, Fertilizer use in Nigeria II. Future Prospects and problems, Institute for Agricultural Research (I.A.R.), Samaru Conference Papers, 1979, 32 - 35.

[8] A. U. Mokwunye, 1981. Phosphorous fertilizers in Nigerian savanna soils: Effect of three phosphorous Sources on available cation content of soil at Samaru, Samaru Journal of Agric. Research (2), 1981, 103 - 109.

[9] A. Abdullahi, and G. Lombin, Long term fertility studies at samara, Nigeria. Comparative Effectiveness of separate and combine applications of mineral fertilizers and farm Yard manure in maintaining soil productivity under continuous cultivation in savanna. Institute for Agricultural Research (I.A.R.), Samaru, Zaria. Miscellaneous paper 75, 1978, 12

[10] S. Sinnandurai, The use of fertilizer on vegetables in Ghana, Tech. Communications of Horticulture (29), 1973, 405

[11] CALU, CARROTS: Crop Production Guides, CALU-the Development centre for horticulture, biomass, novel crops, farm woodlands and novel livestock in Wales, U.K. Ref: 020110, 2007, 1-2, www.calu.bangor.ac.uk (accessed on 11 ${ }^{\text {th }}$ December, 2013).

[12] T. Mazur, and Z. Gronowicz, Nitrogen fertilization of fodder carrot, Field Crop Abstract, $28,1974$.

[13] M. J. Jones, The organic matter content of savanna soils of West Africa, Samaru Research Bulletin, 186, 1973,40 - 53.

[14] V. Balasubrainian, and L. A. Nnadi, Crop residue management and soil productivity in savanna Area of Nigeria, Inorganic Recycling in Africa, FAO Soil Bulletin,43, 1980, 106 - 120

[15] E. O. Uyovbisere, Phosphate uptake as related to extracts fraction in some savanna soils of Nigeria; Unpublished M.Sc. Thesis, Soil science Department, Ahmadu Bello University, Zaria, Nigeria, 1979. 
[16] O. O. Ologunde, Efficient use of fertilizers: Effect of placement method and time of application on grain yield of maize (Zea mays L.) in savanna zones of Northern Nigeria, Paper presented at $1^{\text {st }}$ National Seminar on Green Revolution, Ahmadu Bello University, Zaria, Nigeria, 1981.

[17] H. J. Rosenfeld, R. T. Samuelsen, and P. L. Matforsk, The effect of temperature on sensory quality, chemical composition, and growth of carrots (Daucus carota L.) 1. Constant diurnal temperature, J. Hort. Sc. Biotechnol. 73, 1998, 275-288, in G. J. Hochmuth, J. K. Brecht, and M. J. Bassett, Nitrogen Fertilization to Maximize Carrot Yield and Quality on a Sandy Soil, HortScience, 34(4), 1998, 641-645.

[18] P. W. Simon, C. E. Peterson, and R. C. Lindsay, Genotype, soil and climate effects on sensory and objective components of carrot flavor, J. Amer. Soc. Hort. Sci., 107, 1982, 644-648, in G. J. Hochmuth, J. K. Brecht,and M. J. Bassett, Nitrogen Fertilization to Maximize Carrot Yield and Quality on a Sandy Soil, HortScience 34(4), 1999, 641-645

[19] A. Mozafar, 1993. Nitrogen fertilizers and the amount of vitamins in plants: A review, J. Plant Nutr. 16, 1993, 2479-2506, in G. J. Hochmuth, J. K. Brecht, and M. J. Bassett, Nitrogen Fertilization to Maximize Carrot Yield and Quality on a Sandy Soil, HortScience 34(4), 1999, 641-645

[20] A. M. Evers, 1989. The role of fertilization practices in the yield and quality of carrot (Daucus carota L.). J. Agr. Sci. Finland. 61, 1989,329-360, in G. J. Hochmuth, J. K. Brecht, and M. J. Bassett, Nitrogen Fertilization to Maximize Carrot Yield and Quality on a Sandy Soil. HortScience 34(4), 1989, 641-645

[21] G. J. Hochmuth, J. K. Brecht, and M. J. Bassett, Nitrogen Fertilization to Maximize Carrot Yield and Quality on a Sandy Soil, HortScience 34(4), 1999, 641-645

[22] E. O. Dennison, The Value of FYM in maintaining soil fertility in Northern Nigeria, Empire Journal Of Experimental Agriculture, $39,1961,350356$.

[23] J. O. S. Kogbe, Studies in mineral requirements of Nigerian local leafy vegetables: Effect of poultry manure on yield and yield components of yield of amaranth (Amaranthus candoteus), Nigerian Agric. Journal, 13 (3), 1976, 84 - 97

[24] Anonymous, Vegetation. http://www.nig.vegetation.htm. (accessed on April 21 ${ }^{\text {st }}, 2013$ ).

[25] K. Klinkenberg, and G. M. Higgins, Outline of Northern Nigerian Soils, Nigerian Journal of Science 2, $1968,91-115$

[26] O. W. Snedecor, and W. G. Cochran, Statistical methods, $6^{\text {th }}$ Edition, (IOWA State University Press USA, 1967, 456).

[27] D. B. Duncan, Multiple Range and Multiple F - test. Biometric, 11, 1955, 1 - 42.

[28] T. Mazur, and K. Lakaszuk, Fertilization of fodder carrots with increasing rates of N, P and K, Field Crop Abstract, 32 , 1975

[29] T. Geissler, and K. Rudiger, Appropriate mineral fertilizer application - Gartenban, Humbolt University, Berkin, 27 (6), 1980,168 -169 .

[30] P. T. Orphanos, and V. D. Krentos, Nitrogen and phosphorous fertilization of carrots, Ministry of Agriculture and Natural Resources, Nigeria, Cyperus No. 99, 1988, 8

[31] U.S. Gupta, Crop physiology Advancing Frontiers (Oxford and ABH Publishing Company U. K., 1984). 285 - 310.

[32] J. M. Chavarria, Hand book on phosphate fertilization (ISMA LTD, PARIS, 1985).

[33] A. U. Mokwunye, The role of organic fertilizers in the chemical degradation of Nigerian savanna Soils. Samaru Conf. Paper, 14, 1977.

[34] M. B. Ajakaiye, Organic Manure on Vegetations, Samaru Agric. Newsletter 13 (1), 1971, 9 -10.

[35] A. K. Austin, J. B. Chris, and U. S. Harley, Effect of FYM on growth and yield of carrot, Journal of Hort. Science, $38,1963,22-26$

[36] J. Habber, Quality constituents of carrot as influenced by nitrogen fertilization, Acta Horticulture 29, 1973, 295 - 305

[37] H. Michalik, Effect of fertilizer with macro and micro elements on dry matter, sugar and Carotene contents of carrots, Inslytof warzyw nictawa, skierniwice, Poland, 28, 1985, 141 - 163

[38] G. A. Soloven, and Y. V. Lapushkina, Changes in the contents of ascorbic acid, thiannine, Rivoflavin and carotene in carrots in relation to the rates and ratios of mineral fertilizers, Referativayi Zhurnal II: 55, 1978, 198 (Abstract Source).

[39] UNCTAD, Organic Agriculture and Food Security in Africa. United Nations Conference on Trade and Development/ United Nations Environment Programme (UNEP-UNCTAD) Capacity-building Task Force on Trade, Environment and Development, United Nations (UN), New York and Geneva, 2008, 1-47

[40] G. W. Cooke, Fertilizer for maximum yield (English Language Book Society, Collins $3^{\text {rd }}$ edition, 1982), 1-465

[41] M. A. Altieri, Non-certified agriculture in developing countries, in N. E. I. Sciallaba, and C. Hattam (Eds.), Organic Agriculture, Environment and Food Security, FAO, Rome, 2002.

[42] J. Pretty, Agri-Culture: Reconnecting People, Land and Nature, (Earthscan, London, 2002), in UNCTAD, Organic Agriculture and Food Security in Africa, United Nations Conference on Trade and Development/ United Nations Environment Programme (UNEPUNCTAD), Capacity-building Task Force on Trade, Environment and Development, United Nations (UN), New York and Geneva, 2008, 1-47

[43] E. Ostrom, Social capital: a fad or fundamental concept? Center for the Study of Institutions, Population and Environmental Change, Indiana University, U.S.A., 1998, in UNCTAD, Organic Agriculture and Food Security in Africa. United Nations Conference on Trade and Development/ United Nations Environment Programme. UNEP-UNCTAD Capacity-building Task Force on Trade, Environment and Development. United Nations (UN), New York and Geneva, 2008, 1-47

[44] J. Pretty, Social capital and the collective management of resources. Science, 302, 2003, 1912-1915, in UNCTAD, Organic Agriculture and Food Security in Africa, United Nations Conference on Trade and Development/ United Nations Environment Programme (UNEP-UNCTAD) Capacity-building Task Force on Trade, Environment and Development, United Nations (UN), New York and Geneva, 2008, 1-47

[45] B. E. Sambo, and E. C. Odion, Conservation-Organic Agriculture: Panacea for Enhanced Productivity, Soil Fertility Improvement, Income Growth and Sustainability in the Savannah Regions of Nigeria, Journal of Sustainable Development and Environmental Protection,1 (2), 2011, 123-134 